\title{
The role of intraoperative frozen sections for thyroid nodules
}

\author{
João Paulo Alves de Almeida', Sergio Dias do \\ Couto Netto ${ }^{2}$, Rafael Pinto da Rocha ${ }^{3}$, Elio G. \\ Pfuetzenreiter Jr. ${ }^{4}$, Rogério Aparecido Dedivitis 5
}

Keywords: fna, thyroid neoplasms, frozen sections, sensitivity and specificity, thyroidectomy.

\section{Summary}

\begin{abstract}
$\mathrm{T}_{1}$ he role of intraoperative frozen sections (FS) during thyroidectomy is controversial. Aim: to evaluate the role of FS for thyroid nodules management. Patients and methods: All patients who had thyroid surgery for nodular disease and previous USG-guided FNAB in 2006 were prospectively analyzed. They underwent intraoperative FS evaluation, and the biopsy material was classified as benign, malignant or follicular neoplasm. FNAB, FS and paraffin sections were compared. Results: Under the FS, $54 \%$ of the nodules were benign, 30\% were follicular neoplasms, and 16\% were malignant. All cases considered benign and malignant under the FS evaluation were confirmed through the histological "paraffin" analysis. Since it is not considered a definitive indication for total thyroidectomy, if the follicular neoplasms were classified as "benign" under the FS, their sensitivity, specificity, positive and negative predictive values and global diagnostic accuracy were 69\%, 100\%, 100\%, 91,5\% e 77\%, respectively. Among the 42 cases classified as "follicular neoplasm" under the FNAB, in 1 case the FS conclusion was for papillary carcinoma, in 3 cases as benign (all confirmed through the "paraffin"); and 38 cases continued as "follicular pattern", being 29 follicular adenomas and 9 carcinomas through the "paraffin". Conclusion: The FS is only indicated when the FNAB reports "follicular neoplasm".
\end{abstract}

\footnotetext{
${ }^{1}$ Medical Student - Faculdade de Ciências Médicas da Fundação Lusíada, Santos.

${ }^{2}$ Medical Student - Faculdade de Ciências Médicas da Fundação Lusíada, Santos.

${ }^{3}$ Medical Student - Faculdade de Ciências Médicas da Fundação Lusíada, Santos. ${ }^{4}$ Head and Neck surgery resident - Hospital Ana Costa, Santos.
}

${ }^{5} \mathrm{PhD}$ in Medicine - Graduate Program in Otorhinolaryngology and Head and Neck Surgery - UNIFESP - Escola Paulista de Medicina

Otorhinolaryngology and Head and Neck Programs - Faculdade de Ciências Médicas da Fundação Lusíada; Serviço de Cirurgia de Cabeça e Pescoço do Hospital Ana Costa, Santos; e Serviço de Cirurgia de Cabeça e Pescoço da Irmandade da Santa Casa da Misericórdia de Santos.

Send correspondence to: Rogério A. Dedivitis - Rua Dr. Olinto Rodrigues Dantas 343 conjunto 92 11050-220 Santos SP. E-mail: dedivitis.hns@uol.com.br

This paper was submitted to the RBORL-SGP (Publishing Manager System) on 21 October 2007. Code 4883

The article was accepted on 14 December 2007. 


\section{INTRODUCTION}

The fact that fine needle aspiration (FNA) is a highly accurate preoperative method to be used for the diagnosis of thyroid nodules in cancer detection ${ }^{1}$, and the so-called "follicular neoplasia" still is a dilema'. The value of the intra-operative frozen section (FS) remains controversial while its potential to help the surgeon decide between hemithyroidectomy or total thyroidectomy. The method can potentially avoid a second surgery to remove the contralateral lobe should the surgical specimen reveal malignancy in the histopathology included in paraffin and, alternatively, it can avoid an unnecessary total thyroidectomy which will cause the patient to have to replace levothyroxine forever and increase the chance of the patient developing hypoparathyroidism and damage to the recurrent laryngeal nerve ${ }^{3}$.

The goal of the present investigation is to assess the value of the frozen section regarding decision making when facing a nodular disease of the thyroid gland.

\section{MATERIALS AND METHODS}

During the year of 2006, in a prospective study, 126 patients were consecutively submitted to thyroidectomy because of a thyroid nodular disease, and the nodules were previously assessed by guided FNA. All the patients were submitted to FNA performed by the same ultrasound operator and pathologist and the pathology interpretation was carried out by the same pathologist who participated in the harvesting of the material. During surgery, all the specimens were submitted to intraoperative frozen section test. The histopathology diagnosis of the material embedded in paraffin was available. The present study was approved by the Ethics in Research Committee of the local institution.

The FNA is conducted through a $20 \mathrm{~mL}$ plastic syringe with a 21 gauge needle. Ultrasound was performed by means of a $10 \mathrm{MHz}$ probe and a minimum of three aspirations was normally used without local anesthesia. In case of mixed nodules, the liquid component was initially emptied, and the punction was repeated afterwards. The material collected was assessed by the pathologist, and the liquid was previously centrifuged. All the material collected was fixed in alcohol and dyed by Papanicolaou or HE. The frozen section exam was made with one or two representative sections of the area most likely to present capsular invasion.

The cytopathology specimens were classified as inconclusive, benign (colloid nodule, cyst or thyroiditis), malignant and suspected malignant (specimens which definition of malignancy could not be established, presenting a follicular pattern). The presence of monomorphic epithelial cells or slightly pleomorphic, frequently grouped in micro-follicles or in syncytial masses and showing nuclei with atypia or eosinophilic aspect of Hurthle cells, were all considered follicular pattern. As to the frozen sections, the surgical specimens were classified into inconclusive, benign, malignant and follicular pattern.

The frozen section was compared to the histopathology exam (paraffin), considered gold standard. True positive and true negative cases were defined with basis on the histopathology confirmation of the frozen section, of carcinoma or benign lesion, respectively. Thus, the disagreeing results were classified into false-positive and false-negative. Sensitivity, specificity, the predictive values of the negative and positive tests and the accuracy were calculated.

Following that, the FNA findings were compared to those from the frozen section and the impact of each one in the establishment of the surgical approach (partial or total thyroidectomy) was assessed.

\section{RESULTS}

Comparing the FS with the paraffin histopathology (Gold Standard).

In the present sample, there was no FS deemed inconclusive: 68 nodules (54\%) were benign, 38 (30\%) were follicular neoplasias (we must wait for the results of the paraffin study for a detailed investigation of vascular and capsular invasion) and 20 (16\%) were malignant. Figure 1 compares the FS findings with the histopathology ("paraffin").

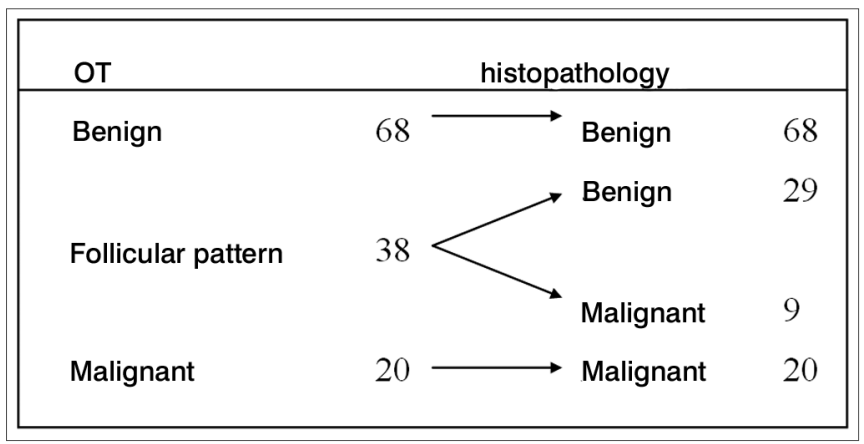

Figure 1. Comparing the FS and the paraffin findings.

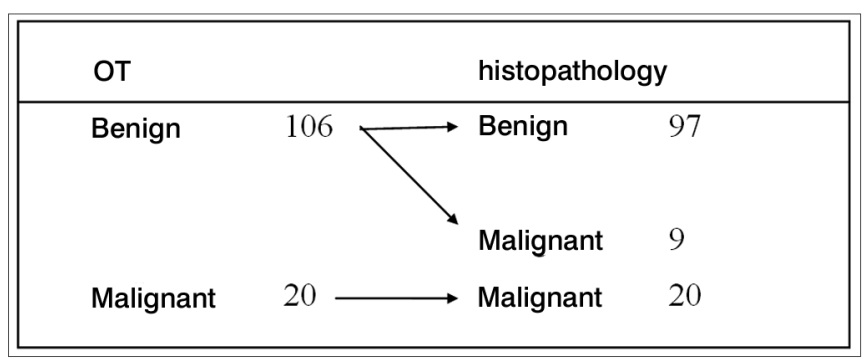

Figure 2. Comparing the FS and the paraffin findings, considering the suspicious punctions (follicular pattern) as being benign. 
Table 1. FS results in the assessment of thyroid nodules.

\begin{tabular}{|c|c|c|c|c|c|c|}
\hline Author & $\mathrm{n}$ & Sensitivity & Specificity & PPV & PNV & Accuracy \\
\hline Bugis et al., $1986^{4}$ & 198 & & & & & $95 \%$ \\
\hline Shaha et al., $1990^{5}$ & 190 & & & & & $95 \%$ \\
\hline Rosen et al., $1990^{6}$ & 457 & $53 \%$ & $100 \%$ & $100 \%$ & $97,8 \%$ & $97,9 \%$ \\
\hline Shaha et al., $1990^{7}$ & 38 & & & & & $95 \%$ \\
\hline Irish et al., $1992^{8}$ & 137 & & & & & $87 \%$ \\
\hline Kingston et al., $1992^{9}$ & 395 & $52 \%$ & $100 \%$ & $100 \%$ & $73 \%$ & $79 \%$ \\
\hline Gibbet al., $1995^{10}$ & 85 & & & & & $86 \%$ \\
\hline McHenry et al., $1996^{11}$ & 76 & $93 \%$ & $100 \%$ & & & $97 \%$ \\
\hline Godei et al., $1996^{12}$ & 2470 & $74 \%$ & $100 \%$ & & & \\
\hline Morosini et al., $1997^{13}$ & 812 & $91,3 \%$ & $100 \%$ & & & $97,4 \%$ \\
\hline Paphavasit et al., $1997^{14}$ & 1023 & $78 \%$ & $99 \%$ & $90 \%$ & $98 \%$ & $98 \%$ \\
\hline Chang et al., $1997^{15}$ & 586 & & & $97 \%$ & $95,5 \%$ & $92,6 \%$ \\
\hline Linder et al., $1997^{16}$ & 73 & $83 \%$ & & $95 \%$ & & \\
\hline Mulcahy et al., $1998^{17}$ & 66 & & & & & $92 \%$ \\
\hline Chen et al., $1998^{18}$ & 57 & $23 \%$ & & & & \\
\hline Hamming et al., $1998^{19}$ & 240 & $67 \%$ & $99 \%$ & $98 \%$ & $87 \%$ & $89 \%$ \\
\hline Tworek et al., $1998^{20}$ & 68 & & $98 \%$ & & & \\
\hline Boyd et al., $1998^{21}$ & 151 & $86 \%$ & $99 \%$ & & & $96 \%$ \\
\hline $\mathrm{Ng} \mathrm{SC}$ et al., $1999^{22}$ & 34 & $100 \%$ & $86 \%$ & & & \\
\hline Chow et al., $1999^{23}$ & 84 & & & & & $100 \%$ \\
\hline Multanen et al., $1999^{24}$ & 335 & $74,6 \%$ & & & & \\
\hline Taneri et al. $2000^{25}$ & 63 & & & $28,5 \%$ & $77,5 \%$ & \\
\hline Piraino et al., $2000^{26}$ & 85 & $89,4 \%$ & & & & \\
\hline Lin et al., $2000^{27}$ & 63 & $87 \%$ & & & & \\
\hline Leteurtre et al., $2001^{28}$ & 63 & $17 \%$ & & & & \\
\hline Tamimi et al., $2001^{29}$ & 61 & $60 \%$ & $100 \%$ & & & $90 \%$ \\
\hline Bastagli et al., $2001^{30}$ & 155 & $42,9 \%$ & $100 \%$ & $100 \%$ & $8,5 \%$ & $92 \%$ \\
\hline Lee et al., $2002^{31}$ & 1076 & & & & & $90,5 \%$ \\
\hline Abboud et al., $2003^{32}$ & 113 & $68 \%$ & $99 \%$ & & & \\
\hline Pisanu et al., $2003^{33}$ & 36 & $33,3 \%$ & & & & \\
\hline Boutin et al., $2003^{34}$ & 163 & $73 \%$ & $99 \%$ & & & \\
\hline Kesmodel et al., $2003^{35}$ & 42 & $36 \%$ & & & & \\
\hline Saydam et al., $2003^{36}$ & 67 & $100 \%$ & $87 \%$ & & & $91 \%$ \\
\hline Callcut et al., $2004^{37}$ & 152 & $67 \%$ & $100 \%$ & $100 \%$ & & $96 \%$ \\
\hline Lumachi et al., $2004^{38}$ & 606 & $83 \%$ & $100 \%$ & & & $97 \%$ \\
\hline Cetin et al., $2004^{39}$ & 203 & $87,1 \%$ & $100 \%$ & & & $97,8 \%$ \\
\hline Rios et al., $2004^{40}$ & 197 & $19 \%$ & $100 \%$ & $100 \%$ & $93 \%$ & $93 \%$ \\
\hline Pisanu et al., $2004^{41}$ & 41 & $33,3 \%$ & & & & \\
\hline Furlan et al., $2004^{42}$ & & $56,1 \%$ & & & & \\
\hline Sahin et al., $2005^{43}$ & & $84 \%$ & $100 \%$ & & & \\
\hline Chao et al., $2005^{44}$ & 135 & $40 \%$ & $100 \%$ & $100 \%$ & $92 \%$ & $92,9 \%$ \\
\hline Dzodic et al., $2006^{45}$ & 40 & $77,7 \%$ & $100 \%$ & $100 \%$ & $94 \%$ & $95 \%$ \\
\hline Giuliani et al., $2006^{46}$ & 417 & $56,25 \%$ & $98,16 \%$ & $81,81 \%$ & $93,85 \%$ & \\
\hline Olson et al., $2006^{47}$ & 236 & $25 \%$ & & & & \\
\hline Miller et al., $2007^{48}$ & 205 & $23 \%$ & $99 \%$ & & & $78 \%$ \\
\hline
\end{tabular}


Among the 20 cases considered malignant at the FS, two were thyroid medullary carcinomas and all the others were papilliferous carcinoma. Among the cases classified as follicular pattern (38), 29 were benign (follicular adenomas) and nine malignant, two cases of follicular carcinoma and seven of papilliferous carcinoma - follicular variant.

If we disregard the follicular pattern punctions, the predictive values for the negative (benign punction) and positive (malignant punction) tests add up to $100 \%$. However, should the FS be suspicious (follicular pattern), it is one indication to perform total thyroidectomy, for the lack of criteria to conclude for malignancy - if classified as "benign", we found a new status (Figure 2).

In this new status, considering the follicular pattern cases (wait for "paraffin" result) as "benign" in the FS, the following values were found: sensitivity $=69 \%$; specificity $=100 \%$; predictive value for the positive test $=$ $100 \%$; predictive value for the negative test $=91.5 \%$; and accuracy $=77 \%$.

\section{Comparing FS with FNA}

All the cases had been submitted to FNA in the preoperative test. Thus, of the 126 nodules punctured, $65(51.6 \%)$ were benign, $42(33.3 \%)$ were follicular neoplasia and 19 (15.1\%) were malignant. Crossing these data with those obtained from the FS exam, we noticed the following:

1) the 19 cases characterized as "malignant" by the FNA were confirmed by the FS and the paraffin;

2) the 65 cases characterized as benign in the FNA were confirmed by the FS and by the paraffin;

3) considering the 42 cases reported as follicular neoplasia by the FNA, we had:

- in one case, the FS found the criteria matching those of papilliferous carcinoma (confirmed by the paraffin test);

- in three cases, FS found enough criteria to define it as being benign (confirmed by the paraffin test);

- in the remaining 38 cases, the FS kept the appearance of a follicular pattern, suggesting that one should wait for the paraffin results; of these, 29 came as follicular adenomas and nine came as carcinoma, two follicular carcinoma and seven papilliferous of the follicular variant.

\section{DISCUSSION}

Table 1 shows the study regarding the results obtained with the FNA on the assessment of thyroid nodules ${ }^{4-48}$.

Our findings match those in the literature, with good accuracy, nonetheless, it also fails when compared to the so called "follicular pattern". Thus, specificity and positive predictive value are high. We found $100 \%$ for both, matching a good part of the data in the literature. This means that, when the FS method points to a cancer possibility, such result is highly reliable. The "follicular pattern" results come with the pathologist's recommendation of waiting for the "paraffin" result, because the criteria necessary for the final diagnosis of malignancy were not found, thus not systematically recommending total thyroidectomy. With this, on the $2 \times 2$ Table such conclusion was classified as "benign" and this justifies the 69\% sensitivity in our sample. Now, when the FNA is considered, the finding of "follicular neoplasia" is a criterion for surgical indication, thus, it must be classified as "malignant"1.

There was a strong correlation between the benign and malignant findings among the FNA guided by ultrasound, FS and histopathology, embedded in "paraffin" (Gold Standard). Thus, when the FNA shows it is benign, or malignant, the FS did not add information. Now, within the 42 cases of "follicular neoplasia" seen at the FNA, in a FS found malignancy criteria, with an impact on the treatment decision and, in three, it was defined that it was a benign lesion.

\section{CONCLUSION}

The FS is only indicated in cases which the FNA yielded results of "follicular neoplasia".

\section{REFERENCES}

1. Rocha RP, Almeida JPA, Couto Netto SD, Silva RABN, Pfuetzenreiter EG, Dedivitis RA. Punção aspirativa por agulha fina guiada por ultrasonografia para nódulos tireoidianos. Rev Bras Cir Cabeça Pescoço. 2007;36(4):186-8.

2. Callcut RA, Selvaggi SM, Mack E, Ozgul O, Warner T, Chen H. The utility of frozen section evaluation for follicular thyroid lesions. Ann Surg Oncol. 2004;11(1):94-8.

3. Wong Z, Muthu C, Craik J, Carter J, Harman CR. Role of intraoperative frozen section in the management of thyroid nodules. ANZ J Surg. 2004;74(12):1052-5.

4. Bugis SP, Young JE, Archibald SD, Chen VS. Diagnostic accuracy of fine-needle aspiration biopsy versus frozen section in solitary thyroid nodules. Am J Surg. 1986;152(4):411-6.

5. Shaha A, Gleich L, Di Maio T, Jaffe BM. Accuracy and pitfalls of frozen section during thyroid surgery. J Surg Oncol. 1990;44(2):84-92.

6. Rosen Y, Rosenblatt P, Saltzman E. Intraoperative pathologic diagnosis of thyroid neoplasms. Report on experience with 504 specimens. Cancer .1990;66(9):2001-6.

7. Shaha AR, DiMaio T, Webber C, Jaffe BM. Intraoperative decision making during thyroid surgery based on the results of preoperative needle biopsy and frozen section. Surgery. 1990;108(6):964-7.

8. Irish JC, van Nostrand AW, Asa SL, Gullane P, Rotstein L. Accuracy of pathologic diagnosis in thyroid lesions. Arch Otolaryngol Head Neck Surg. 1992;118(9):918-22.

9. Kingston GW, Bugis SP, Davis N. Role of frozen section and clinical parameters in distinguishing benign from malignant follicular neoplasms of the thyroid. Am J Surg. 1992;164(6):603-5.

10.Gibb GK, Pasieka JL. Assessing the need for frozen sections: still a valuable tool in thyroid surgery. Surgery. 1995;118(6):1005-9; discussion 1009-10.

11.McHenry CR, Raeburn C, Strickland T, Marty JJ. The utility of routine frozen section examination for intraoperative diagnosis of thyroid cancer. Am J Surg. 1996;172(6):658-61. 
12.Godey B, Le Clech G, Inigues JP, Legall F, Beust L, Bourdiniere J. [Extemporaneous anatomo-pathological test in surgery of thyroid cancers. Values and limitations] Lexamen anatomo-pathologique extemporané dans la chirurgie des cancers thyroïdiens. Intérêts et limites. Ann Otolaryngol Chir Cervicofac. 1996;113(4):219-24.

13.Morosini PP, Mancini V, Filipponi S, Taccaliti A, Ferretti M, Gusella P, Vecchi A, Fianchini A, Fabris G. [Comparison between the diagnostic accuracy in diagnosis of thyroid nodules with fine needle biopsy an intraoperative histological evaluation of frozen tissue] Raffronto dellaccuratezza diagnostica nella diagnosi dei noduli tiroidei fra biopsia con ago sottile e valutazione istologica intraoperatoria su tessuto congelato. Minerva Endocrinol. 1997;22(1):1-5

14.Paphavasit A, Thompson GB, Hay ID, Grant CS, van Heerden JA, Ilstrup DM, Schleck C, Goellner JR. Follicular and Hurthle cell thyroid neoplasms. Is frozen-section evaluation worthwhile? Arch Surg. 1997;132(6):674-8; discussion 678-80

15.Chang HY, Lin JD, Chen JF, Huang BY, Hsueh C, Jeng LB, Tsai JS. Correlation of fine needle aspiration cytology and frozen section biopsies in the diagnosis of thyroid nodules. J Clin Pathol. 1997;50(12):1005-9.

16.Linder R, Sahin G, Grimm H. [Value of preoperative diagnosis in struma surgery] Die Wertigkeit der präoperativen Diagnostik in der Strumachirurgie. Langenbecks Arch Chir Suppl Kongressbd. 1997;114:1142-4.

17.Mulcahy MM, Cohen JI, Anderson PE, Ditamasso J, Schmidt W. Relative accuracy of fine-needle aspiration and frozen section in the diagnosis of well-differentiated thyroid cancer. Laryngoscope. 1998;108 (4 Pt 1):494-6.

18.Chen H, Nicol TL, Zeiger MA, Dooley WC, Ladenson PW, Cooper DS, Ringel M, Parkerson S, Allo M, Udelsman R. Hurthle cell neoplasms of the thyroid: are there factors predictive of malignancy? Ann Surg. 1998;227(4):542-6

19.Hamming JF, Vriens MR, Goslings BM, Songun I, Fleuren GJ, van de Velde CJ. Role of fine-needle aspiration biopsy and frozen section examination in determining the extent of thyroidectomy. World J Surg. 1998;22(6):575-9; discussion 579-80.

20.Tworek JA, Giordano TJ, Michael CW. Comparison of intraoperative cytology with frozen sections in the diagnosis of thyroid lesions. Am J Clin Pathol. 1998;110(4):456-61.

21.Boyd LA, Earnhardt RC, Dunn JT, Frierson HF, Hanks JB. Preoperative evaluation and predictive value of fine-needle aspiration and frozen section of thyroid nodules. J Am Coll Surg. 1998;187(5):494-502.

22.Ng SC, Lin JD, Huang BY, Chen CH, Hsueh C, Lee N, Yen TC. Diagnosis and management of 34 Hurthle cell tumors. Changgeng Yi Xue Za Zhi. 1999;22(3):445-52

23.Chow TL, Venu V, Kwok SP. Use of fine-needle aspiration cytology and frozen section examination in diagnosis of thyroid nodules. Aust $\mathrm{N} \mathrm{Z} \mathrm{J}$ Surg. 1999;69(2):131-3.

24.Multanen M, Haapiainen R, Leppäniemi A, Voutilainen P, Sivula A. The value of ultrasound-guided fine-needle aspiration biopsy (FNAB) and frozen section examination (FS) in the diagnosis of thyroid cancer. Ann Chir Gynaecol. 1999;88(2):132-5.

25.Taneri F, Tekin E, Salman B, Anadol AZ, Ersoy E, Poyraz A, Onuk E. Huerthle cell neoplasms of the thyroid: predicting malignant potential. Endocr Regul. 2000;34(1):19-21.

26.Piraino P, Sepúlveda A, Lillo R, Pineda P, Liberman C. [Thyroid cancer. Report of 85 cases] Cáncer tiroideo. Comunicación de 85 casos. Rev Med Chil. 2000;128(4):405-10.

27.Lin HS, Komisar A, Opher E, Blaugrund SM. Follicular variant of papillary carcinoma: the diagnostic limitations of preoperative fine-needle aspiration and intraoperative frozen section evaluation. Laryngoscope. 2000;110(9):1431-6

28.Leteurtre E, Leroy X, Pattou F, Wacrenier A, Carnaille B, Proye C, LecomteHoucke M. Why do frozen sections have limited value in encapsulated or minimally invasive follicular carcinoma of the thyroid? Am J Clin Pathol. 2001;115(3):370-4

29.Tamimi DM. Value of routine frozen section diagnosis of thyroid lesions. Saudi Med J. 2001;22(11):995-8.
30.Bastagli A, de Pasquale L, Schubert L. [Follicular neoplasm of the thyroid: usefulness of extemporaneous histologic study of frozen sections] Neoplasia follicolare della tiroide: utilità dellesame istologico estemporaneo al congelatore. Ann Ital Chir. 2001;72(3):283-6.

31.Lee TI, Yang HJ, Lin SY, Lee MT, Lin HD, Braverman LE, Tang KT. The accuracy of fine-needle aspiration biopsy and frozen section in patients with thyroid cancer. Thyroid. 2002;12(7):619-26.

32.Abboud B, Allam S, Chacra LA, Ingea H, Tohme C, Farah P. Use of fineneedle aspiration cytology and frozen section in the management of nodular goiters. Head Neck. 2003;25(1):32-6.

33.Pisanu A, Aste L, Piu S, Cois A, Uccheddu A. [Predictive factors for malignancy in Hurthle-cell thyroid neoplasia. Effect of surgical treatment] Fattori predittivi di malignità nelle neoplasie tiroidee a cellule di Hurthle. Influenza sul trattamento chirurgico. Tumori. 2003;89(4 Suppl):223-5.

34.Boutin P, Bozorg Grayeli A, Terrada C, Rondini-Gilli E, Mosnier I, Julien N, Bouccara D, Groussard O, Bok B, Sterkers O. [Results of fine needle aspiration biopsy, frozen section diagnosis and definite histological results in thyroid pathology. Report of 163 cases] Analyse des résultats de la cytoponction, de lexamen histologique extemporané et définitif dans le traitement chirurgical de la pathologie thyroïdienne: à propos de 163 cas. Rev Laryngol Otol Rhinol. (Bord) 2003;124(1):59-63.

35.Kesmodel SB, Terhune KP, Canter RJ, Mandel SJ, LiVolsi VA, Baloch $\mathrm{ZW}$, Fraker DL. The diagnostic dilemma of follicular variant of papillary thyroid carcinoma. Surgery. 2003;134(6):1005-12; discussion 1012.

36.Saydam L, Kalcioglu MT, Kizilay A, Bozkurt MK. [The evaluation of thyroid nodules: is routine use of frozen-section examination necessary following preoperative fine-needle aspiration biopsy?] Tiroit nodullerinin degerlendirilmesi: Ince igne aspirasyon biyopsisinden sonra frozen section incelemesi gerekli mi? Kulak Burun Bogaz Ihtis Derg. 2003;11(3):80-4.

37.Callcut RA, Selvaggi SM, Mack E, Ozgul O, Warner T, Chen H. The utility of frozen section evaluation for follicular thyroid lesions. Ann Surg Oncol. 2004;11(1):94-8

38.Lumachi F, Borsato S, Tregnaghi A, Marino F, Poletti A, Iacobone M, Favia G. Accuracy of fine-needle aspiration cytology and frozen-section examination in patients with thyroid cancer. Biomed Pharmacother. 2004;58(1):56-60.

39. Cetin B, Asian S, Hatiboglu C, Babacan B, Onder A, Celik A, Cetin A. Frozen section in thyroid surgery: is it a necessity? Can J Surg. 2004;47(1):2933.

40.Ríos Zambudio A, Rodríguez González JM, Sola Pérez J, Soria Cogollos T, Galindo Fernández PJ, Parrilla Paricio P. Utility of frozen-section examination for diagnosis of malignancy associated with multinodular goiter. Thyroid. 2004;14(8):600-4.

41.Pisanu A, Sias L, Uccheddu A. Factors predicting malignancy of Hurthle cell tumors of the thyroid: influence on surgical treatment. World J Surg. 2004;28(8):761-5.

42.Furlan JC, Bedard YC, Rosen IB. Role of fine-needle aspiration biopsy and frozen section in the management of papillary thyroid carcinoma subtypes. World J Surg. 2004;28(9):880-5.

43.Sahin M, Allard BL, Yates M, Powell JG, Wang XL, Hay ID, Zhao Y, Goellner JR, Sebo TJ, Grebe SK, Eberhardt NL, McIver B. PPARgamma staining as a surrogate for PAX8/PPARgamma fusion oncogene expression in follicular neoplasms: clinicopathological correlation and histopathological diagnostic value. J Clin Endocrinol Metab. 2005;90(1):463-8.

44.Chao TC, Lin JD, Chen MF. Surgical treatment of Hurthle cell tumors of the thyroid. World J Surg. 2005;29(2):164-8

45.Dzodic R, Markovic I, Inic M, Jokic N, Djurisic I, Zegarac M, Pupic G, Milovanovic Z, Jovic V, Jovanovic N. Sentinel lymph node biopsy may be used to support the decision to perform modified radical neck dissection in differentiated thyroid carcinoma. World J Surg. 2006;30(5):841-6.

46.Giuliani D, Willemsen P, Verhelst J, Kockx M, Vanderveken M. Frozen section in thyroid surgery. Acta Chir Belg. 2006;106(2):199-201.

47. Olson S, Cheema Y, Harter J, Starling J, Chen H. Does frozen section alter surgical management of multinodular thyroid disease? J Surg Res. 2006;136(2):179-81.

48.Miller MC, Rubin CJ, Cunnane M, Bibbo M, Miller JL, Keane WM, Pribitkin EA. Intraoperative pathologic examination: cost effectiveness and clinical value in patients with cytologic diagnosis of cellular follicular thyroid lesion. Thyroid. 2007;17(6):557-65. 